\title{
Induction of $\beta$-Platelet-derived Growth Factor Receptor in Rat Hepatic Lipocytes during Cellular Activation In Vivo and in Culture
}

\author{
Linda Wong, ${ }^{*}$ Glenn Yamasaki, ${ }^{*}$ Richard J. Johnson, ${ }^{\ddagger}$ and Scott L. Friedman* \\ *University of California, San Francisco Liver Center Laboratory and Medical Service, San Francisco General Hospital, San Francisco, \\ California 94110; and ${ }^{\ddagger}$ Division of Nephrology, Department of Medicine, University of Washington, Seattle, Washington 98195
}

\begin{abstract}
A consistent response to liver injury is the activation of resident mesenchymal cells known as lipocytes (Ito, fat-storing cells) into a proliferating cell type. In cultured lipocytes, platelet-derived growth factor (PDGF) is the most potent proliferative cytokine, but requires the activation-dependent expression of its receptor protein (Friedman, S. L., and M. J. P. Arthur. 1989. J. Clin. Invest. 84:1780-1785); the role of PDGF receptor (PDGFR) in liver injury is unknown. We have examined PDGFR gene expression in freshly isolated lipocytes during liver injury and correlated these findings with a culture model of cellular activation. Whereas lipocytes from normal rats had no detectable transcript for the $\beta$-PDGFR subunit, this mRNA was induced within $1 \mathrm{~h}$ after a dose of carbon tetrachloride $\left(\mathrm{CCl}_{4}\right)$. In contrast, $\alpha$ subunit mRNA was detected in normal cells, but was unchanged after liver injury. Similar results were observed in lipocytes from bile duct-obstructed rats, although $\beta$-PDGFR induction was less marked. By immunoblot, induction of $\beta$-PDGFR protein in lipocytes isolated from $\mathrm{CCl}_{4}$-treated animals correlated with mRNA increases. In contrast to lipocytes, endothelial cells from normal liver expressed low levels of $\alpha$ - and $\beta$-receptor subunit mRNA, which did not increase with injury. Using a $\beta$-PDGFR antibody, receptor protein could be identified within fibrotic septa in $\mathrm{CCl}_{4}$ treated animals in regions where cells expressed proliferating cell nuclear antigen (PCNA). In cultured lipocytes activated by growth on uncoated plastic, $\beta$-PDGFR transcripts appeared within $3 \mathrm{~d}$ after plating, which coincided with the onset of cellular proliferation. In contrast, quiescent cells in suspension culture had no detectable $\beta$-PDGFR mRNA. These results indicate that $\beta$-PDGF receptor induction by lipocytes is an early event during hepatic injury in vivo and in primary culture. (J. Clin. Invest. 1994. 94:1563-1569.)

Key words: hepatic fibrosis - liver injury • Ito cells • fatstoring cells $\cdot$ proliferation
\end{abstract}

\section{Introduction}

The early cellular response to hepatic injury has been wellstudied in animal models and human disease. In $\mathrm{CCl}_{4}$-induced

Address correspondence to Scott L. Friedman, MD, San Francisco General Hospital, Liver Center Laboratory, 1001 Potrero Avenue, Bldg. 40, Rm 4102, San Francisco, CA 94110.

Received for publication 19 November 1993 and in revised form 9 June 1994

J. Clin. Invest.

(c) The American Society for Clinical Investigation, Inc.

0021-9738/94/10/1563/07 \$2.00

Volume 94, October 1994, 1563-1569 liver injury, for example, early infiltration by mononuclear cells is followed by proliferation of mesenchymal cells, development of fibrotic septa, and ultimately formation of nodules encased by dense scar tissue (1-3). Accumulating evidence indicates that the septal mesenchymal cells are activated lipocytes, cells which in normal liver express desmin (2) and are the primary site for storing hepatic vitamin A (4). After injury, lipocytes are the major site of extracellular matrix gene expression $(5,6)$, and are thought to play a central role in formation of the hepatic scar (for review see reference 7).

A major element of the injury response by lipocytes is their activation into myofibroblast-like cells. This phenotypic transformation has been well characterized in situ, and includes new expression of smooth muscle $\alpha$ actin (2), enlargement of the secretory apparatus (8), increased pericellular matrix (9), and proliferation (10). Mechanisms underlying the proliferative component of lipocytes activation have been partly elucidated using primary culture models. Cells isolated from normal rats are initially nonproliferative when grown on uncoated plastic; cell replication accompanies progressive culturing on plastic $(11,12)$. Proliferation can be accelerated by exposing cells to conditioned medium from hepatic macrophages (13); this model is particularly relevant to the in vivo response, because, as noted, macrophage infiltration always precedes mesenchymal cell proliferation in parenchymal injury (1).

In culture studies of lipocyte proliferation, platelet-derived growth factor (PDGF) has been identified as the principal mitogen $(13,14)$. Responsiveness to PDGF requires expression of a specific dimeric transmembrane receptor (PDGFR) ${ }^{1}$, which is composed of either $\alpha \alpha, \alpha \beta$, or $\beta \beta$ subunits (15). Indeed, in cultured lipocytes activated by exposure to conditioned medium from macrophages, proliferation is preceded by induction of PDGF receptor protein as assayed by immunoblot (13).

While these culture studies have suggested that PDGF receptor induction is an important component of lipocyte activation, proof has been lacking that a similar event occurs in vivo. Additionally, the cellular distribution and receptor phenotype of PDGF receptor have not been studied in normal and injured liver. Evidence from analogous models of wound healing, especially in kidney (16) and skin (17), suggest that in vivo expression of PDGF receptor could also be an important event in hepatic injury, and, moreover, might offer a potential target for therapeutic intervention.

In this study we have characterized PDGF receptor expression in two mechanistically distinct models of liver injury in vivo, both in situ and by examining freshly isolated cell populations, and have correlated these findings with culture models of lipocyte activation. The results indicate that after injury in vivo

1. Abbreviations used in this paper: PDGFR, platelet-derived growth factor receptor. 


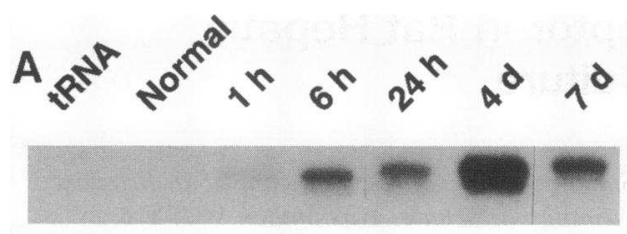

$\beta$-PDGFR

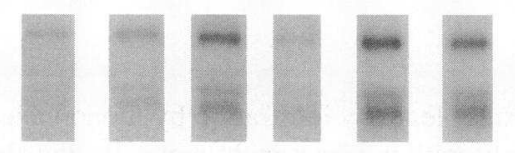

S14
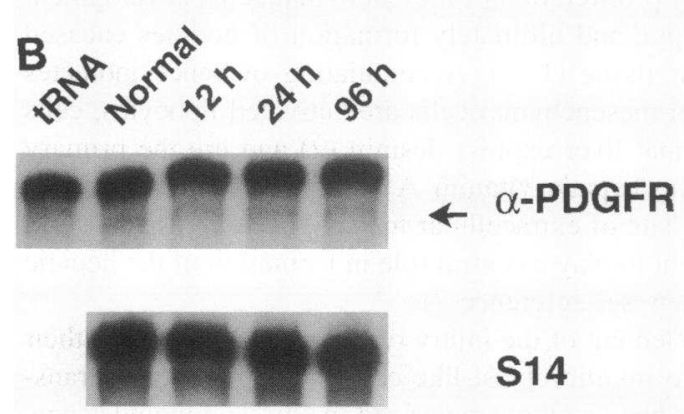

S14

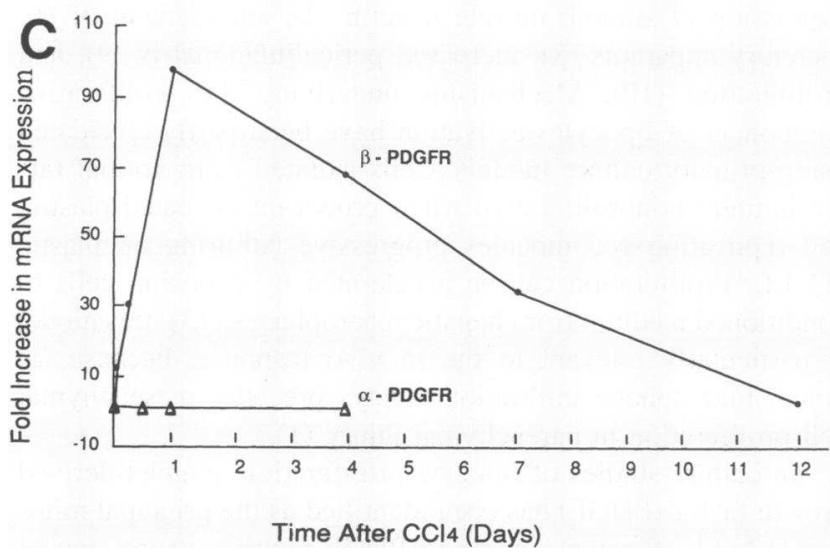

Figure 1. In vivo expression of $\alpha$ - and $\beta$-PDGFR mRNA by rat lipocytes after $\mathrm{CCl}_{4}$. $(A$ and $B$ ) Freshly isolated lipocytes from either untreated rats or after a single dose of $\mathrm{CCl}_{4}$ were analyzed for expression of $\beta$ and $\alpha$-isoforms of PDGFR by RNAse protection. Protected fragments of $458 \mathrm{bp}$ for the $\beta$-isoform and $466 \mathrm{bp}$ for the $\alpha$-isoform are evident; for the $\alpha$-isoform the arrow indicates the specific band. Each sample contained $0.5 \mu \mathrm{g}$ mRNA; corresponding expression of S14 mRNA is shown below each sample. $C$ depicts relative receptor mRNA expression normalized for $\mathrm{S} 14$ in the same isolate, with cells from normal liver assigned a value of 1 .

in rats, induction of $\beta$ - but not $\alpha$-PDGF receptor mRNA occurs rapidly, and is accompanied by evidence of receptor protein in situ. Moreover, receptor gene induction is confined to lipocytes and is not observed in the other prominent mesenchymal cell type, sinusoidal endothelial cells. In lipocyte culture models cellular proliferation is also closely tied to the appearance of $\beta$-PDGF receptor mRNA.

\section{Methods}

In vivo models of liver injury

Hepatic fibrosis was induced by either bile duct ligation or carbon tetrachloride $\left(\mathrm{CCl}_{4}\right)$ administration. Bile duct ligation and scission were
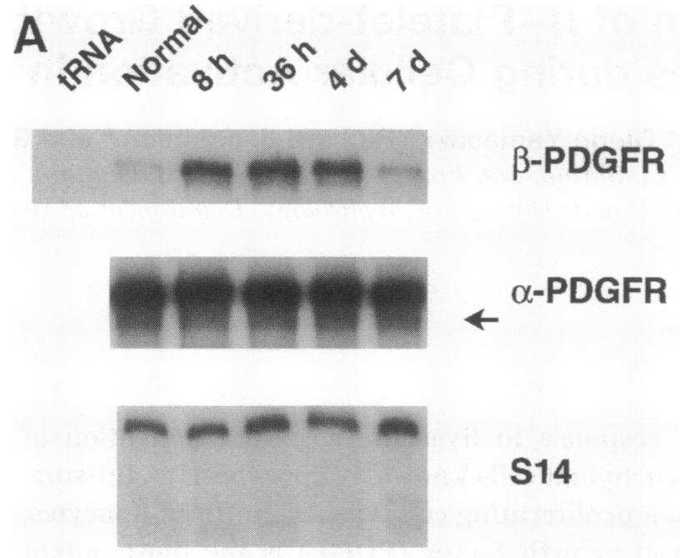

S14

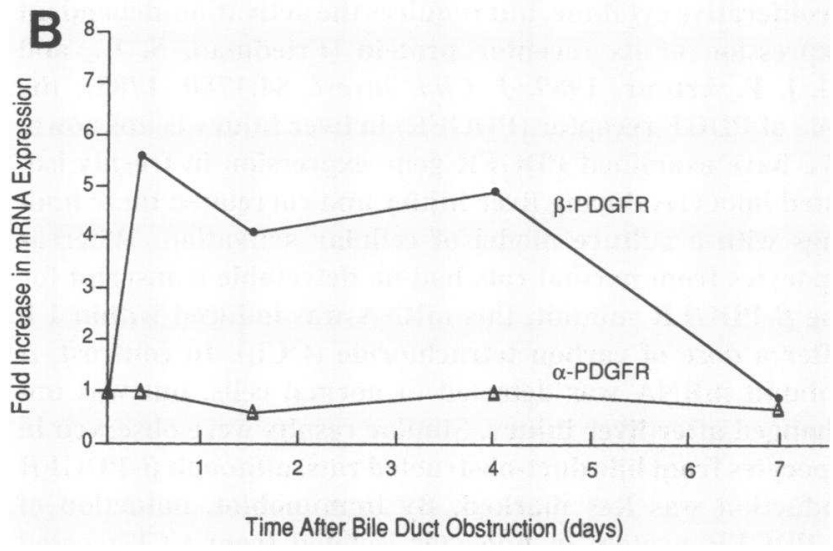

Figure 2. In vivo expression of $\alpha$ and $\beta$-PDGFR mRNA by rat lipocytes after bile duct obstruction. $(A)$ Freshly isolated lipocytes from either normal animals or after bile duct ligation were analyzed by RNAse protection for expression of $\beta$ - and $\alpha$-PDGFR mRNA. Samples contained $5 \mu \mathrm{g}$ total RNA; corresponding S14 mRNA expression is shown. (B) Relative PDGFR mRNA expression normalized for S14 expression.

performed under ether anesthesia (18). For all studies except immunostaining, a single dose of corn oil:CCl ${ }_{4}(1: 1)(1 \mu \mathrm{l} / \mathrm{g}$ body wt.) was administered by gavage to ether-anesthetized animals (19); for immunostaining at day 8 , animals received doses of $\mathrm{CCl}_{4}$ on days 1 and 5. Rats were maintained on standard chow and allowed access to food and water ad libitum.

\section{Cell isolation and culture}

Lipocytes were isolated from Sprague-Dawley retired breeder rats by pronase/collagenase perfusion and Stractan gradient centrifugation as described previously (20). Endothelial cells, collected from the bottom two interfaces of the gradient $(8-12 \%, 12-15 \%)$, were purified further by centrifugal elutriation at $2,500 \mathrm{rpm}$ at a flow rate of $18 \mathrm{ml} / \mathrm{min}$. (J221 centrifuge with JE 6-B rotor and Sanderson chamber; Beckman Instruments, Inc., Fullerton, CA). Purity of isolates was $\sim 95 \%$ and was assessed by direct cell counting using anti-desmin as a marker for lipocytes, and DiI-conjugated acetoacetylated low-density lipoprotein for endothelial cells. Lipocytes were also identified by the vitamin A autofluorescence under ultraviolet epillumination. Yields per animal were $30-40 \times 10^{6}$ cells for lipocytes and $10-20 \times 10^{6}$ for endothelial cells.

Experiments were performed using either freshly isolated cells or cells in primary culture. For culture studies, lipocytes were suspended in medium 199 OR with $10 \%$ horse and $10 \%$ calf serum at a concentration of $10^{6}$ cells per ml. Cells were maintained in either suspension culture in teflon-coated containers (Savillex Corp., Minnetonka, MN) 
or in monolayer culture on uncoated plastic plates (Lux Scientific, Naperville, IL). Our earlier studies have shown that lipocytes in suspension culture are nonproliferative and negative for smooth muscle $\alpha$ actin; activation can be induced if cells are transferred to monolayer culture (21). All cultures were incubated at $37^{\circ} \mathrm{C}$ in $100 \%$ humidity, $95 \% 0_{2}$, and $5 \% \mathrm{CO}_{2}$, without agitation. Medium was changed every $48 \mathrm{~h}$.

\section{PDGF receptor immunoblot}

Immunoblot of lipocyte extracts was performed using a polyclonal antibody to rat $\beta$-PDGF receptor subunit generated against a mixture of synthetic peptides of the human and mouse $\beta$ subunit, as previously described (22). Cells were isolated from either normal or $\mathrm{CCl}_{4}$-treated animals, and maintained in suspension culture for $24 \mathrm{~h}$ in $20 \%$ serum (21) before lysis directly into electrophoresis buffer (3\% SDS, $62.5 \mathrm{mM}$ Tris- $\mathrm{HCl}, 10 \%$ glycerol, and $2 \% \beta$-mercaptoethanol, $\mathrm{pH}$ 6.8). Protein content ( $75 \mu \mathrm{g} / \mathrm{lane}$ ) was normalized by Bio Rad protein assay (BioRad Laboratories, Richmond, CA) before 8\% SDS-polyacrylamide gel electrophoresis and overnight transfer to nylon. The primary antibody was used at a dilution of 1:1,500, and secondary antibody (goat antirabbit conjugated to horseradish peroxidase) at 1:2,000.

\section{$P D G F$ receptor $m R N A$ expression}

Expression of mRNA for $\alpha$ and $\beta$-PDGF receptors was measured in freshly isolated in vivo or cultured cells by RNAse protection assay using rat-specific cRNA probes.

\section{Rat $\alpha$ - and $\beta$-PDGF receptor cDNAs}

$\beta$-PDGF receptor. A 458-bp rat cDNA fragment was cloned by "homology" polymerase chain reaction (PCR), using degenerate primers based on the published human $\beta$-PDGF receptor amino acid sequence (aa 588-746) (23). Primer sequences were constructed to include EcoRI and XbaI restriction sites: forward - 5' CTCCC TCTAGA CCITA(TC)GA(TC)(AT)(GC)IACITGGGA 3' ; reverse - 5' CTCCC GAATTC TC(AG)TC(CT)TTI(CG)(TA)CAT(AG)TCCAT(AG)TA 3'. $1 \mu \mathrm{g}$ cDNA derived from activated lipocytes was used as a template, prepared as follows: total RNA was isolated from 6-10 d cultured rat cells $(\sim 100$ $\times 10^{6}$ cells). mRNA was extracted using a commercial kit (PolyATract mRNA Isolation System; Promega, Madison, WI) from $250 \mu \mathrm{g}$ total RNA. First strand cDNA was synthesized using Avian Myeloblastosis Virus reverse transcriptase and oligo dT primers (Promega). PCR was conducted in a $50 \mu \mathrm{l}$ reaction using a thermal cycler (Ericomp, San Diego, CA): 1 cycle $\left(94^{\circ} \mathrm{C} \times 4 \mathrm{~min}\right) ; 30$ cycles $\left(95^{\circ} \mathrm{C} \times 45 \mathrm{~s}, 45^{\circ} \mathrm{C}\right.$ for $\left.45 \mathrm{~s}, 72^{\circ} \mathrm{C} \times 60 \mathrm{~s}\right) ; 1$ cycle $\left(72^{\circ} \mathrm{C} \times 10 \mathrm{~min}\right)$. The product was visualized by electrophoresis through $1.5 \%$ low-melting agarose containing ethidium bromide and purified using phenol/chloroform. The $\beta$-PDGF receptor cDNA was cloned into pGEM-4 (Promega) and sequenced by the dideoxy chain termination method (24) (Sequenase Version 2.0; United States Biochemical Corp., Cleveland, $\mathrm{OH}$ ). After these cloning studies were completed, a partial cDNA for the rat $\beta$-PDGFR sequence which incorporated this region was entered into Genbank by others (accession No. Z14119, unpublished).

$\alpha-P D G F$ receptor. A 466-bp BamHI fragment of the published cDNA sequence for the rat $\alpha$-PDGF receptor (25) (provided by Dr. Daniel Bowen Pope, University of Washington) was subcloned into pGEM-4. The plasmid was linearized with BstXI for use as a template for riboprobe synthesis.

\section{RNAse protection assay}

RNAse protection assay was performed exactly as described by Maher and McGuire (6), using $1.0 \mu \mathrm{g}$ of linearized plasmid template DNA to synthesize a rat specific cRNA probe. Either $0.5 \mu \mathrm{g}$ of mRNA or $5 \mu \mathrm{g}$ of total RNA (specified in Figure Legends) was used in the overnight hybridization with the probe $\left(60^{\circ} \mathrm{C}\right)$. mRNA was directly isolated using Invitrogen Micro-Fast Tract ${ }^{\oplus}$ kit (Invitrogen, San Diego, CA) according to manufacturer's specifications; total RNA was extracted and purified according to Chomczynski and Sacchi (26).

All autoradiographs were quantitated by laser densitometry. Data from in vivo experiments were normalized for expression of the ribo-

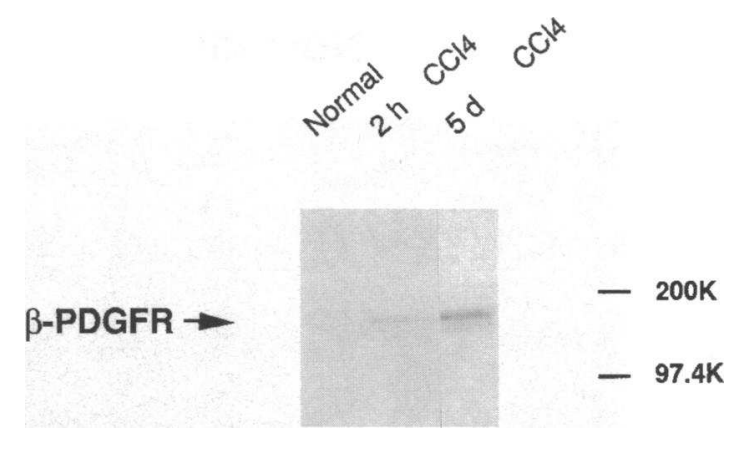

Figure 3. Immunoblot of $\beta$-PDGF receptor in lipocytes activated in vivo. Lipocytes were isolated from a normal rat and from animals treated with $\mathrm{CCl}_{4}$ either $2 \mathrm{~h}$ or $5 \mathrm{~d}$ before isolation. After $24 \mathrm{~h}$ of suspension culture to allow receptor recovery, cell extracts were analyzed for $\beta$ PDGFR expression as described in Methods. Increased expression of the $180-\mathrm{kD}$ receptor is detectable within $2 \mathrm{~h}$ of $\mathrm{CCl}_{4}$, and clearly visible in cells from an animal treated $5 \mathrm{~d}$ earlier (the location of the molecular weight standards is shown in the right hand margin).

somal S14 protein mRNA (27). For culture experiments equal RNA amounts were assured by measuring $\mathrm{OD}_{260}$ and inspection of 28 and 18 $S$ ribosomal bands on agarose/formaldehyde electrophoresis.

\section{Immunohistochemistry of rat liver}

For immunostaining, liver fragments were excised and fixed in Methyl Carnoy's solution; $3-\mu \mathrm{m}$ sections were examined. Tissue staining was performed using an indirect avidin/biotin immunoperoxidase method exactly as previously described (22). Primary antibody was either a polyclonal IgG to the $\beta$ subunit of PDGFR (9 $\mu \mathrm{g} / \mathrm{ml})(22)$, a murine monoclonal IgM to proliferating cell nuclear antigen, (PCNA) (American Biotech, Plantation, FL), or a murine monoclonal IgG (ED-1) to monocytes-macrophages (Bioproducts for Science, Inc., Indianapolis, IN) (22). Tissue sections were also incubated with the following negative control primary antibodies: rabbit non-immune IgG (for $\beta$-PDGFR) or an irrelevant murine monoclonal antibody (for ED-1 and PCNA).

Tissue sections were photographed with a Nikon Microphot ${ }^{\otimes}$ microscope using Kodak T-Max film (ASA 100) (Eastman Kodak Co., Rochester, NY)

\section{Cell proliferation assay}

Cells from normal rats were plated on uncoated plastic in 24-well dishes and assayed for the incorporation of $\left[{ }^{3} \mathrm{H}\right]$ thymidine exactly as described previously (11). Data were normalized for cell number.

\section{Results}

In lipocytes from normal liver, $\beta$-PDGFR mRNA was undetectable. A transcript was apparent within $1 \mathrm{~h}$ after $\mathrm{CCl}_{4}$, which increased to maximal at $24 \mathrm{~h}$ (Fig. 1, $A-C$ ); there was a greater than 100-fold relative increase between 1 and $24 \mathrm{~h}$. Receptor mRNA levels returned to normal within $12 \mathrm{~d}$ after a single dose.

To assess whether induction of the $\beta$-PDGFR was common to different forms of liver injury, we examined its expression after ligation of the common bile duct, a form of liver injury mechanistically distinct from $\mathrm{CCl}_{4}$. Receptor mRNA induction was rapid (within $8 \mathrm{~h}$ ) and sustained for at least $4 \mathrm{~d}$, although to a much lesser extent than in $\mathrm{CCl}_{4}(\sim 5.5$-fold maximal increase) (Fig. 2, $A-C$ ).

In contrast to the $\beta$ isoform, expression of $\alpha$-PDGFR mRNA was apparent in lipocytes from normal liver, but was unchanged after either $\mathrm{CCl}_{4}$ or bile duct ligation (Figs. 1 and 2).

Two approaches were used to correlate induction of $\beta$ - 
Normal

ED-1
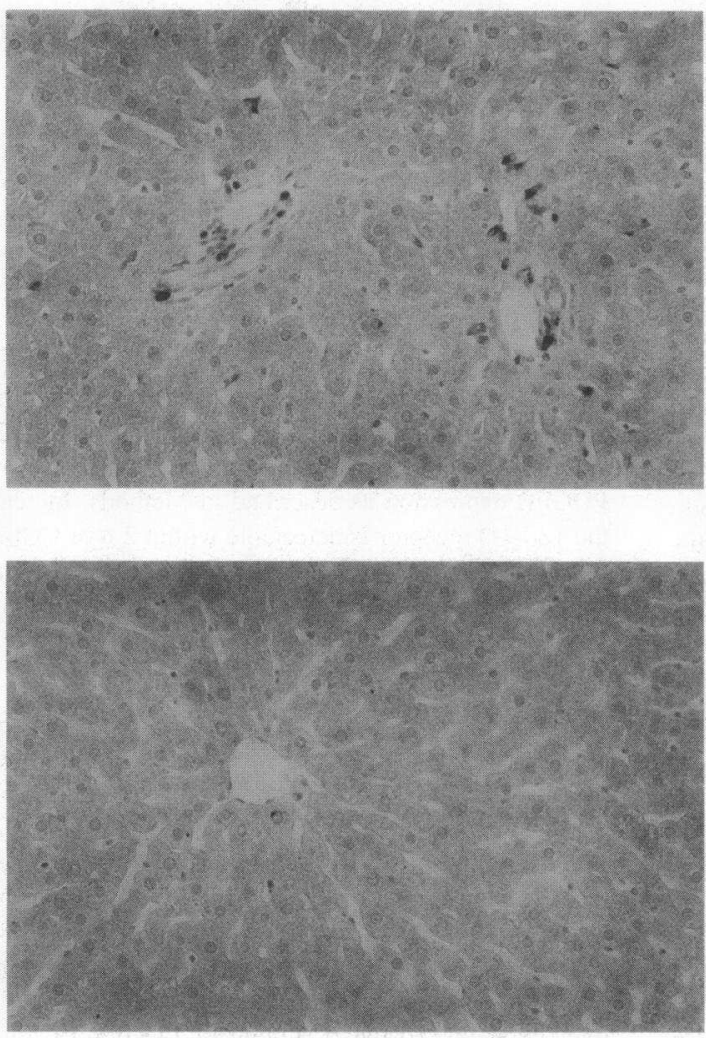

PCNA

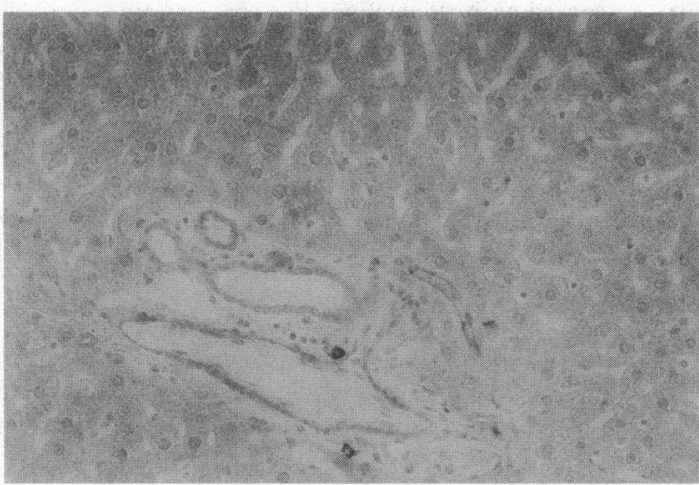

$8 \mathrm{~d} \mathrm{CCl}_{4}$
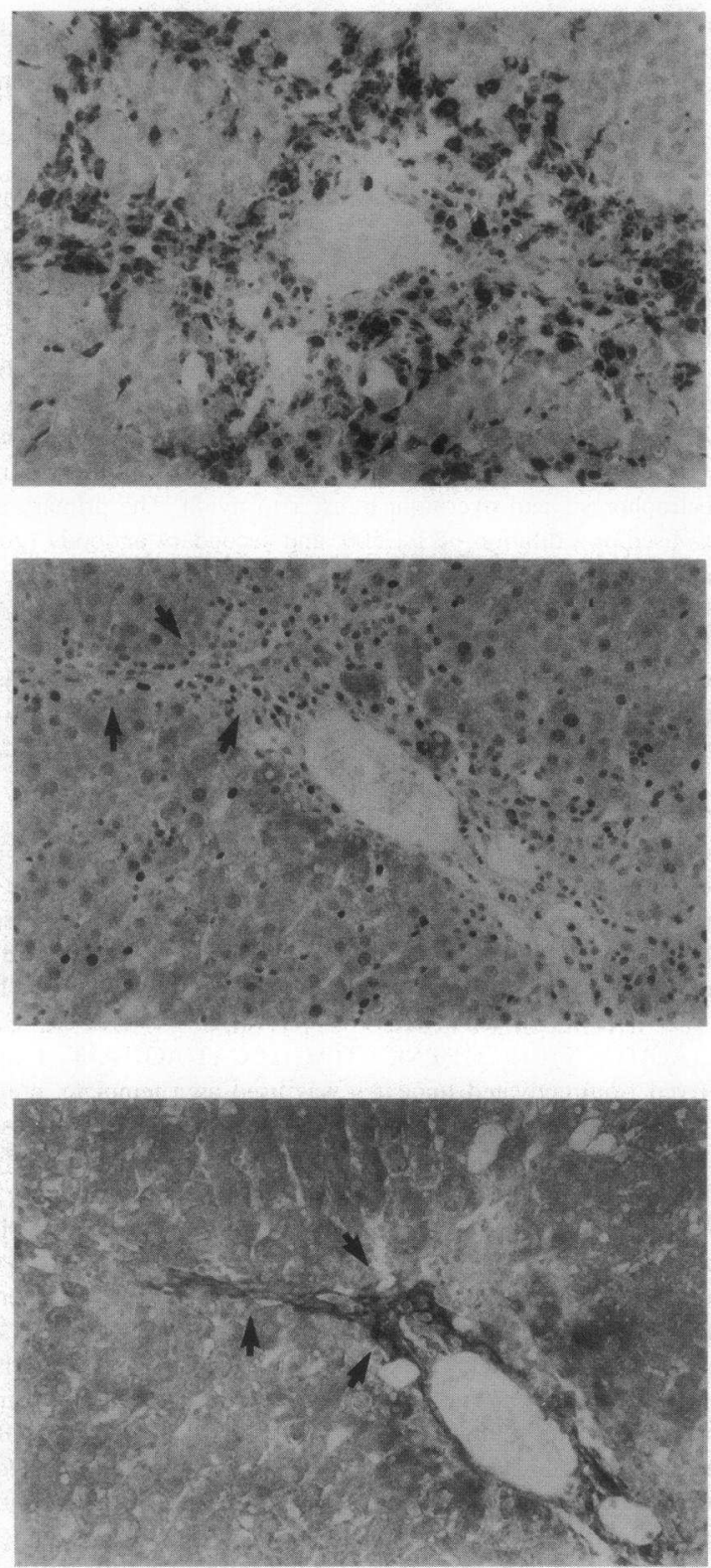

Figure 4. Immunostaining of rat liver following $\mathrm{CCl}_{4}$ administration. Liver from either normal rats or animals treated with two doses of $\mathrm{CCl}_{4}$ on days 1 and 5 before harvest on day 8 were examined for expression of ED-1, proliferating cell nuclear antigen (PCNA) and $\beta$-PDGFR by immunostaining. Scattered ED-1 positive cells (darkly stained cells) are apparent in normal liver. At $8 \mathrm{~d}$, marked mononuclear cell infiltration in forming septa is apparent (dark cells). Similarly, in normal liver few cells expressing PCNA are seen, but positive cells are readily observed within $8 \mathrm{~d}$ (darkened nuclei). In normal liver, $\beta$-PDGFR is evident only around large arterial walls, but becomes detectable within $8 \mathrm{~d}$ of $\mathrm{CCl}_{4}$ in septa which contain PCNA-positive cells (the same region is highlighted with arrows in parallel tissue sections stained for PCNA and $\beta$-PDGFR). There was no background immunoreactivity at all time points using appropriate negative control antibodies (not shown).

PDGFR mRNA with expression of the receptor. First, in cells isolated from normal or $\mathrm{CCl}_{4}$-treated rats then maintained in brief suspension culture, increased receptor protein was apparent within $2 \mathrm{~h}$ after $\mathrm{CCl}_{4}$, and markedly increased $5 \mathrm{~d}$ after dosing (Fig. 3); cells were placed in suspension culture to allow for reappearance of receptors cleaved by proteases during isolation. Second, in situ expression was identified in liver sections from normal and $\mathrm{CCl}_{4}$-treated rats immunostained with a $\beta$ PDGFR antibody. Receptor immunoreactivity was apparent in fibrotic septa at day 8 after two doses of $\mathrm{CCl}_{4}$ in regions of PCNA positivity (Fig. 4). This distribution corresponds to $\alpha$ smooth muscle-expressing activated lipocytes $(2,28,29)$ and was accompanied by a marked increase in macrophage infiltration as determined by staining with the macrophage marker ED1 (Fig. 4).

To determine the cellular specificity of PDGFR mRNA expression in vivo, we asayed $\alpha$ - and $\beta$-PDGFR gene expression in sinusoidal endothelial cells from normal and bile-duct-li- 

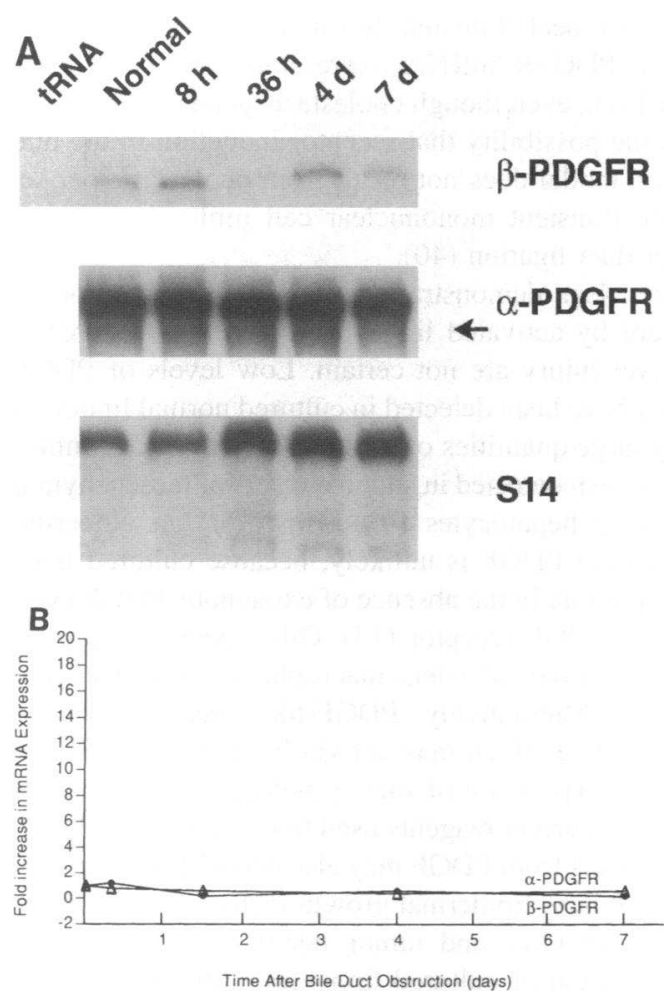

Figure 5. In vivo expression of $\alpha$ and $\beta$-PDGFR by sinusoidal endothelial cells after bile duct obstruction. $(A)$ Endothelial cells from normal rats or following bile duct obstruction were analyzed by RNAse protection for $\beta$ and $\alpha$ isoforms. $5 \mu \mathrm{g}$ total RNA was used per sample, with corresponding S14 mRNA expression shown for each sample. (B) Relative changes and time course of expression.

gated animals. Low levels of $\alpha$ - and $\beta$-PDGFR transcripts were present in cells from normal animals, but neither was induced after liver injury (Fig. 5).

Assessment of $\beta$-PDGFR mRNA levels under culture conditions which we have previously associated with cellular replication confirmed that a proliferative phenotype correlated with induction of receptor mRNA. Specifically, cells grown on uncoated plastic expressed receptor mRNA at $72 \mathrm{~h}$ after plating, coincident with onset of cellular proliferation as assessed by incorporation of $\left[{ }^{3} \mathrm{H}\right]$ thymidine (Fig. 6). In contrast, cells maintained in a quiescent phenotype by suspension culture remained spherical and nonproliferative, with undetectable $\beta$-PDGFR mRNA (Fig. 7).

\section{Discussion}

In this study we demonstrate that acute liver injury in rats is accompanied by induction of $\beta$-PDGFR mRNA and protein. Receptor gene induction is associated with in situ cell proliferation, and is restricted to hepatic lipocytes and not sinusoidal endothelia, the other potential PDGFR-expressing cell type in liver parenchyma. We further show that $\beta$-PDGFR mRNA is also induced under culture conditions in which PDGF or serumdependent lipocyte proliferation occurs $(8,11,14)$.

Induction of PDGF receptor has not previously been documented in liver injury in vivo, although upregulation of PDGFR appears to be a major means of amplifying the proliferative
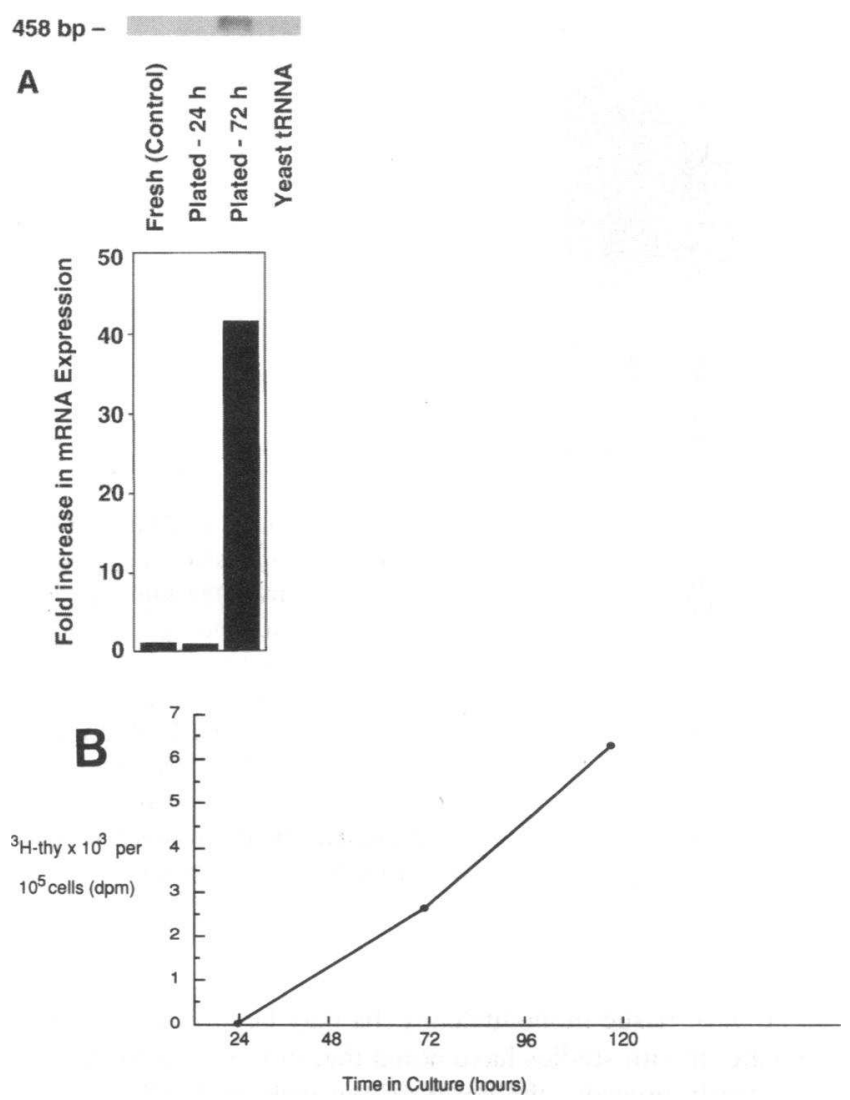

Figure 6. Expression of $\beta$-PDGFR mRNA and cellular proliferation by lipocytes from normal rat liver at isolation or in monolayer culture. $(A)$ $5 \mu \mathrm{g}$ of total RNA from the same lipocyte isolate was examined for $\beta$ PDGFR mRNA expression at the time of isolation, and 24 and $72 \mathrm{~h}$ after plating on uncoated plastic in serum-containing medium. The presence of equal quantities of RNA in each sample was confirmed by absorbance at $\mathrm{OD}_{260}$ and intensity of $28 \mathrm{~S}$ and $18 \mathrm{~S}$ ribosomal bands on formaldehyde/agarose electrophoresis (not shown). Relative mRNA expression is graphically depicted, with samples from freshly isolated cells assigned a value of 1 . $(B)$ The time course of cellular proliferation in cells maintained in monolayer culture, as assessed by incorporation of $\left[{ }^{3} \mathrm{H}\right]$ thymidine. Data points represent mean value of triplicate determinations normalized for cell number.

response of mesenchymal cells in several other forms of tissue injury. In particular, arterial injury (30), renal injury (22), tissue rejection (31), and synovitis (32) all are associated with in situ expression of PDGFR. In each of these tissues the $\beta$ isoform is induced. Predominant expression of the $\beta$ isoform is also consistent with previous observations in cultured rat lipocytes $(33,34)$. In contrast to the $\beta$ subunit, expression of the $\alpha$ subunit mRNA is detectable in normal cells, but is not increased with injury. Although the specific band for $\alpha$-PDGFR mRNA using RNAse protection was subtle, it nonetheless likely reflects a genuine signal, because we have also detected $\alpha$-PDGFR mRNA in lipocytes by reverse transcriptase-polymerase chain reaction (S. Friedman, unpublished results). Despite this apparent mRNA expression, however, significant expression of functional $\alpha$ receptor by lipocytes is unlikely based on the lack of responsiveness of culture-activated lipocytes to PDGF AA $(33,34)$.

Factors directly responsible for the induction of $\beta$-PDGFR in our and related models are not yet established, but the accu- 

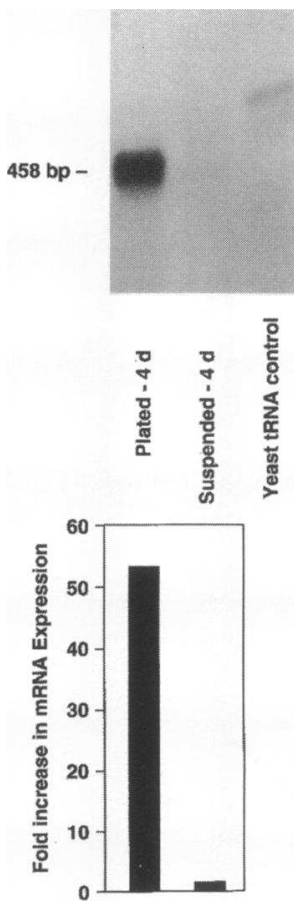

Figure 7. Expression of $\beta$-PDGFR mRNA in cultured lipocytes; plated vs suspension culture. Lipocytes from the same isolate were either plated in monolayer culture on plastic or grown in suspension culture, both in the presence of serum. $5 \mu \mathrm{g}$ from each isolate (quantitated as described in Fig. 5 legend) were analyzed by RNAse protection. Autoradiograph and relative increases depicted graphically are shown, with the sample from plated cells assigned a value of 1

mulation of tissue mononuclear cells may be an important prerequisite. In situ studies have noted that in liver this infiltration consistently precedes the onset of mesenchymal cell proliferation $(1,3)$. Moreover, in our earlier study using cultured lipocytes, receptor expression was accelerated by exposure to macrophage-conditioned medium (13). Nonetheless, results from other studies $(11,12,35)$ suggest that macrophage products are not essential for induction of PDGF-mediated proliferation in cultured lipocytes, and that serum-dependent proliferation will occur once cells have spread. A similar observation has been made in smooth muscle cells (36). The importance of cell spreading for cellular activation and $\beta$-PDGFR induction is underscored by the lack of cell proliferation (21) or $\beta$-PDGFR gene expression in cells maintained in suspension culture, similar to an earlier report of PDGFR downregulation in cell lines during suspension (37).

We confined our experiments to time points within 2 wk after injury, because our primary interest is in mechanisms of early lipocyte activation. Accumulated evidence indicates that lipocyte activation is a complex cascade of cellular events involving alterations in both structural and regulatory genes (38). Therapeutic efforts to control lipocyte activation will likely be most meaningful if directed towards these early changes, when activation is reversible.

While injury induced by either $\mathrm{CCl}_{4}$ or bile duct ligation was associated with $\beta$-PDGFR mRNA induction, the relative increase in gene expression in $\mathrm{CCl}_{4}$ disease was more marked than in bile duct obstruction. The basis for this difference is not known, but could be related to the extent of necrosis and inflammation. Carbon tetrachloride results in extensive parenchymal injury due to membrane disruption, with a marked inflammatory response $(1,39)$. In contrast, parenchymal injury and inflammation are present but more subtle in rats with bile duct obstruction (40). On the other hand, the return to normal of $\beta$-PDGFR mRNA expression within 1 wk after a single dose of $\mathrm{CCl}_{4}$ is consistent with the known reversibility of this lesion in the absence of repeated dosing. Surprisingly, even after bile duct ligation, $\beta$-PDGFR mRNA expression returned to near normal within $1 \mathrm{wk}$, even though cholestasis persists. This finding reinforces the possibility that receptor induction in the bile duct obstruction model does not result from cholestasis per se, but rather from transient mononuclear cell infiltration, which peaks $3 \mathrm{~d}$ after duct ligation (40).

Despite the clear demonstration of PDGFR induction in vivo and culture by activated lipocytes, the cellular source(s) of PDGF in liver injury are not certain. Low levels of PDGF A-chain mRNA have been detected in cultured normal lipocytes when assaying large quantities of RNA (34), and PDGF immunoreactivity has been detected in situ in clusters of mesenchymal cells and necrotic hepatocytes (41). However, an autocrine source for bioactive PDGF is unlikely, because cultured lipocytes fail to proliferate in the absence of exogenous PDGF even when expressing PDGF receptor (13). Other potential sources for PDGF in vivo include platelets, macrophages, and sinusoidal endothelial cells. Alternatively, PDGF-like species have recently been described which may act via binding to the PDGF receptor $(42,43)$; expression of such a molecule in liver might elude detection by current reagents used to detect native PDGF. Other mitogens apart from PDGF may also drive lipocyte proliferation in tissue injury. Epidermal growth factor $(14,44)$, fibroblast growth factor (14), and tumor necrosis factor (45) all stimulate proliferation of cultured lipocytes, although they are less potent than PDGF (14).

\section{Acknowledgments}

We gratefully acknowledge the assistance of Pam Pritzl and Maureen Reilly (University of Washington) for performing all tissue immunostaining and Dr. Ron Seifert for providing the $\beta$-PDGFR antibody. We thank Dr. William Jarnagin for providing cellular RNA samples from bile-duct-obstructed animals and Janet Doherty for assistance with manuscript preparation.

This work is supported by grants from the National Institutes of Health (DK-37340 and AM-26743 to S. L. Friedman, DK-43422 and DK-02142 to R. J. Johnson) and the American Heart Association, California Chapter (grant 92-211A to S. L. Friedman).

\section{References}

1. Johnson, S. J., J. E. Hines, and A. D. Burt. 1992. Macrophage and perisinusoidal cell kinetics in acute liver injury. J. Pathol. 166:351-358.

2. Rockey, D. C., J. K. Boyles, G. Gabbiani, and S. L. Friedman. 1992. Rat hepatic lipocytes express smooth muscle actin upon activation in vivo and in culture. J. Submicrosc. Cytol. Pathol. 24:193-203.

3. Geerts, A., P. Schellinck, L. Bouwens, and E. Wisse. 1988. Cell population kinetics of Kupffer cells during the onset of fibrosis in rat liver by chronic tetrachloride administration. J. Hepatol. 6:50-56.

4. Hendriks, H. F. J., W. A. M. M. Verhoofstad, A. Brouwer, A. M. de Leeuw, and D. L. Knook. 1985. Perisinusoidal fat-storing cells are the main vitamin A storage sites in rat liver. Exp. Cell Res. 160:138-149.

5. Milani, S., H. Herbst, D. Schuppan, E. G. Hahn, and H. Stein. 1989. In situ hybridization for procollagen types I, III and IV mRNA in normal and fibrotic rat liver: evidence for predominant expression in nonparenchymal liver cells. Hepatology. 10:84-92.

6. Maher, J. J. and R. F. McGuire. 1990. Extracellular matrix gene expression increases preferentially in rat lipocytes and sinusoidal endothelial cells during hepatic fibrosis in vivo. J. Clin. Invest. 86:1641-1648.

7. Friedman, S. L. 1993. The cellular basis of hepatic fibrosis. N. Engl. J. Med. 328:1828-1835.

8. Horn, T., J. Junge, and P. Christoffersen. 1985. Early alcoholic liver injury: changes of the Disse space in acinar zone 3. Liver. 5:301-310.

9. Minato, Y., Y. Hasumura, and J. Takeuchi. 1983. The role of fat-storing cells in Disse space fibrogenesis in alcoholic liver disease. Hepatology. 3:559566. 
10. Geerts, A., J-M. Lazou, P. DeBleser, and E. Wisse. 1991. Tissue distribution, quantitation, and proliferation kinetics of fat-storing cells in carbon tetrachloride-injured liver. Hepatology. 13:1193-1202.

11. Friedman, S. L., F. J. Roll, J. Boyles, D. M. Arenson, and D. M. Bissell. 1989. Maintenance of differentiated phenotype of cultured rat hepatic lipocytes by basement membrane matrix. J. Biol. Chem. 264:10756-10762.

12. Friedman, S. L. and F. J. Roll. 1987. Isolation and culture of hepatic lipocytes, Kupffer cells, and sinusoidal endothelial cells by density gradient centrifugation with Stractan. Anal. Biochem. 161:1233-1247.

13. Friedman, S. L. and M. J. P. Arthur. 1989. Activation of cultured rat hepatic lipocytes by Kupffer cell conditioned medium. J. Clin. Invest. 84:17801785.

14. Pinzani, M., L. Gesualdo, G. M. Sabbah, and H. E. Abboud. 1989. Effects of platelet-derived growth factor and other polypeptide mitogens on DNA synthesis and growth of culture rat liver fat-storing cells. J. Clin. Invest. 84:1786-1793.

15. Seifert, R. A., C. E. Hart, P. E. Phillips, J. W. Forstrom, R. Ross, M. J. Murray, and D. F. Bowen-Pope. 1989. Two different subunits associate to create isoform-specific platelet-derived growth factor receptors. J. Biol. Chem. 264:8771-8778.

16. Fellstrom, B., L. Klareskog, C. H. Heldin, E. Larsson, L. Ronnstrand, L. Terracio, G. Tufveson, and J. Wahlberg. 1989. Platelet-derived growth factor receptors in the kidney -- Upregulated expression in inflammation. Kidney Int. 36:1099-1102.

17. Reuterdahl, C., C. Sundberg, K. Rubin, K. Funa, and B. Gerdin. 1993 Tissue localization of beta receptors for platelet-derived growth factor and plateletderived growth factor B chain during wound repair in humans. J. Clin. Invest. 91:2065-2075.

18. Kountouras, J., B. H. Billing, and P. J. Scheuer. 1984. Prolonged bile duct obstruction: a new experimental model for cirrhosis in the rat. Br. J. Exp. Pathol. 65:305-311.

19. Proctor, E., and K. Chatamra. 1982. High yield micronodular cirrhosis in the rat. Gastroenterology. 83:1183-90.

20. Friedman, S. L. 1993. Isolation and culture of hepatic nonparenchymal cells. Methods Toxico. 1:292-310.

21. Friedman, S. L., Yamasaki, G., and L. Wong. 1994. Modulation of TGF $\beta$ receptors in rat hepatic lipocytes during the hepatic wound healing response; enhanced binding but reduced gene expression accompany cellular activation in culture and in vivo. J. Biol. Chem., 269:10551-10558.

22. Iida, H., R. Seifert, C. E. Alpers, R. G. K. Gronwald, P. E. Phillips, P Pritzl, K. Gordon, and A. M. Gown. 1991. Platelet-derived growth factor (PDGF) and PDGF receptor are induced inmesangial proliferative nephritis in the rat. Proc. Natl. Acad. Sci. USA. 88:6560-6564.

23. Gronwald, R. G. K., F. J. Frant, B. A. Haldeman, C. E. Hart, P. J. O'Hara, F. S. Hagen, R. Ross, and D. F. Bowen-Pope. 1988. Cloning and expression of a cDNA coding for the human platelet-derived growth factor receptor: evidence for more than one receptor class. Proc. Natl. Acad. Sci. USA. 85: 3435-3439.

24. Sanger, F., A. R. Coulson, G. F. Hong, D. F. Hill, and G. B. Petersen. 1982. Nucleotide sequence of bacteriophage lambda DNA. J. Mol. Biol. 162:729773.

25. Lee, K.-H., D. F. Bowen-Pope, and R. R. Reed. 1990. Isolation and characterization of the $\alpha$ platelet-derived growth factor receptor from rat olfactory epithelium. Mol. Cell. Biol. 10:2237-2246.

26. Chomczynski, P. and N. Sacchi. 1987. Single-step method of RNA isolation by acid guanidinium thiocyanate-phenol-chloroform extraction. Anal. Biochem. 162:156-159.

27. Rhoads, D. D., A. Dixit, and D. J. Roufa. 1986. Primary structure of human ribosomal protein S14 and the gene that encodes it. Mol. Cell. Biol. 6:2774-2783.
28. Tanaka, Y., K. M. Mak, and C. S. Lieber. 1990. Immunohistochemical detection of proliferating lipocytes in regenerating rat liver. J. Pathol. 160:129134.

29. Ramadori, G., T. Veit, S. Schwogler, H. P. Dienes, T. Knittel, H. Rieder, and K. H. Meyer zum Buschenfelde. 1990. Expression of the gene of the alphasmooth muscle-actin isoform in rat liver and in rat fat-storing (ITO) cells. Vir chows Arch. B. Cell Pathol. 59:349-357.

30. Majesky, M. W., M. A. Reidy, D. F. Bowen-Pope, C. E. Hart, J. N. Wilcox, and S. M. Schwartz. 1990. PDGF ligand and receptor gene expression during repair of arterial injury. J. Cell Biol. 111:2149-2158.

31. Fellstrom, B., E. Dimeny, E. Larsson, L. Klareskog, G. Tufveson, and K Rubin. 1989. Importance of PDGF receptor expression in accelerated atherosclerosis-chronic rejection. Transplant. Proc. 21:3689-3691.

32. Rubin, K., G. K. Hansson, L. Ronnstrang, L. Claesson-Welsh, B. Fellstrom, A. Tingstrom, E. Larsson, and L. Klareskog. 1988. Induction of b-type receptors for platelet-derived growth factor in vascular inflammation: possible implications for development of vascular proliferative lesions. Lancet. i:13531356.

33. Heldin, P., H. Pertoft, H. Nordlinder, C. H. Heldin, and T. C. Laurent. 1991. Differential expression of platelet-derived growth factor alpha- and beta receptors on fat-storing cells and endothelial cells of rat liver. Exp. Cell Res. 193:364-369.

34. Pinzani, M., T. C. Knauss, G. F. Pierce, P. Hsieh, W. Kenney, G. R. Dubyak, and E. Abboud. 1991. Mitogenic signals for platelet-derived growth factor isoforms in liver fat-storing cells. Am. J. Physiol. 260:C485-C491.

35. Davis, B. H., U. R. Rapp, and N. O. Davidson. 1991. Retinoic acid and transforming growth factor beta differentially inhibit platelet derived growth factor induced Ito-cell activation. Biochem. J. 278:43-47.

36. Terracio, L., L. Ronnstrand, A. Tingstrom, K. Rubin, L. Claesson-Welsh, K. Funa, and C. -H. Heldin. 1988. Induction of platelet-derived growth factor receptor expression in smooth muscle cells and fibroblasts upon tissue culturing. J. Cell Biol. 107:1947-1957.

37. Grundy, P., S. Bishayee, S. Disa, and C. D. Scher. 1989. Modulation of platelet-derived growth factor receptor function in BP3T3, a chemically transformed BALB/c-3T3 cell line. Cancer Res. 49:3581-3586.

38. Friedman, S. L., G. Yamasaki, L. Wong, S. Burd, and A. Lalazar. 1993. Subtraction cloning of lipocyte activating genes. Hepatology. 18:107A.

39. Williams, A. T. and R. F. Burk. 1990. Carbon tetrachloride hepatotoxicity: an example of free radical-mediated injury. Semin. Liver Dis. 10:279-284.

40. Hines, J. E., S. J. Johnson, and A. D. Burt. 1993. In vivo responses of macrophages and perisinusoidal cells to cholestatic liver injury. Am. J. Pathol. 142:511-518.

41. Pinzani, M., Milani, S., Grappone, C., Takeichi, N., and Moriuchi, T. 1994. Expression of platelet-derived growth factor in a model of acute liver injury. Hepatology. 19:701-707.

42. Kumar, R. K., R. A. Bennett, and A. R. Brody. 1988. A homologue of platelet-derived growth factor produced by rat alveolar macrophages. FASEB (Fed. Am. Soc. Exp. Biol.) J. 2:2272-2277.

43. Matsuoka, J. and G. R. Grotendorst. 1989. Two peptides related to plateletderived growth factor are present in human wound fluid. Proc. Natl. Acad. Sci. USA. 86:4416-4420.

44. Bachem, M. G., U. Riess, and A. M. Gressner. 1989. Liver fat storing cell proliferation is stimulated by epidermal growth factor/transforming growth factor alpha and inhibited by transforming growth factor beta. Biochem. Biophys. Res. Commun. 162:708-714.

45. Matsuoka, M., N-T. Pham, and H. Tsukamoto. 1989. Differential effects of interleukin-1 alpha, tumor necrosis factor alpha, and transforming growth factor beta 1 on cell proliferation and collagen formation by cultured fat-storing cells. Liver. 9:71-78. 